УДК 628.94

\title{
The technique of calculating the profile of a mirror reflector for discharge lamps of cylindrical shape and its testing on the example of design of an industrial lamp type ZhSP-250
}

\author{
Ye. Lobanov \\ O.M. Beketov National University of Urban Economy \\ in Kharkiv, \\ Ukraine \\ Email: lobanov.kh@gmail.com
}

\author{
G. Petchenko \\ O.M. Beketov National University of Urban Economy \\ in Kharkiv, \\ Ukraine \\ Email: gdaeron@ukr.net
}

\begin{abstract}
Current scientific trends are developments methodological, theoretical and experimental, related to increasing the efficiency of some categories of lamps with discharge lamps. One such category is the powerful industrial spotlight class luminaires. This work is aimed at solving the urgent scientific task of finding ways to improve the design efficiency of industrial luminaires with deep and concentrated light distribution. At present, there are practically no works related to the task of calculating the geometry of the profiles of mirrored round-symmetric reflectors, which, in the presence of a light source of a fixed type and power, would provide the necessary light distribution of the luminaires. The elemental reflection method described in classical works does not determine the geometry of the reflector correctly, which provides the necessary balance in the equation that relates the light power of the lamp to the light power of the source and the reflector. The considerable time of calculation by the classical method and obtaining inaccurate decisions leads to rethinking the solution of the problem of calculating the geometry of the the reflector profile of the lamp with rigidly regulated light distribution. This task was first formulated by us in previous works. The purpose of this work is to approve the technique of solving the inverse problem of determining the geometry of a round-symmetric mirror reflector on the example of an industrial lamp type ZhKU-250 with light distribution type G-2. As the output of the calculation we used the light source and technical characteristics of the light source - DNAT-250 lamps, the required light distribution of the light fixture, the reflectance of the reflector, and the requirements for the efficiency of the designed luminaire and its gain. As a result of the performed work, it is possible to note the efficiency of the method both in terms of the accuracy of the calculations and the simple geometry of the reflector, obtained in the calculation method, which will allow to use simplified technological schemes for the serial production of such lamps.
\end{abstract}

Keywords - industrial luminaires, DNaT discharge lamps, reflector LPC (Light Power Curve) required, zone LPCs of the reflector, radius vector array, luminaire gain and efficiency, elemental reflection method, reflector profile, rotary extrusion method.

\section{INTRODUCTION}

Today modern lighting devices require not only the observance of the necessary light distribution, which is regulated in accordance with the nature and conditions of their operation, but also in accordance with the tasks of energy saving and ecology. If we analyze the overall market situation of the lighting products of Ukraine and the neighboring countries of the EU, it is possible to record the turbulent dynamics of the LED lighting market. So LEDs have become seriously entrenched in the market for indoor and outdoor lighting: local lighting, indoor lighting, facade and architectural lighting, decorative and stage lighting, transportation lighting, and more. Practically, it is possible to state unlimited domination in the market of lighting products of lighting devices on LED basis, if not but for one thing. Powerful DRI and DNaT discharge lamps cannot compete with their LED counterparts, but they do have certain unconditional advantages that keep them on the market. The first and the most famous is the low price. This advantage is, in fact, highly debatable, as the low cost of discharge lamps and luminaires for them quickly becomes a trap for developers of appropriate lighting because of the significant power consumption of the respective lighting systems and the significant degradation of the lighting characteristics of such luminaires over time. In contrast to the mentioned, their LED counterparts have their drawbacks in that sense - LEDs are more vulnerable to external climatic factors and, therefore, have deviations in their regulated characteristics unlike discharge lamps that are purely structural $\neg-$ due to the presence of a vacuum layer between the outer flask and the burner, they are more stable with respect to variations in ambient temperature. The second advantage is the spectral range of the discharge lamps. If you need to design street or industrial lighting, for example, to develop and apply a light fixture to illuminate a highway or foundry at a metallurgical plant, a white LED light would not be the best solution for the developer. The spectral range of luminaires for such tasks should be at a maximum in the orange range. The explanation is simple such a spectrum is the most effective stimulus for the human eyes, which is particularly relevant in the context of the reduced transparency of the atmosphere in which light of such spectral range is spread.

In addition, some of the visual work in industrial plants (such as visual melt temperature control) is associated with the use of orange light. In the open access there are reports on the increase in the number of road accidents on the streets and highways of cities caused by white-range LED 
lighting. We must be aware that the primary purpose of lighting is the most effective solution to the problem of performing visual work of a certain level of complexity. The fact that the highway will be illuminated by energyefficient light is a positive thing, but the truth is that the road must be lit in such a way that it performs its function as much as possible - for example, providing a certain level of passenger flow while respecting the conditions of passenger traffic safety.

The third, and perhaps the most important advantage of discharge lamps is the significant luminous flux of these devices (more than $10^{4} \mathrm{Lm}$ ). On average, it exceeds 3-4 times the corresponding characteristics for LED devices. To adequately compensate one street light fixture with an ZhKU lamp on the street, several LED analogs must be used, which is not attractive in terms of the high cost of such lighting.

Given this, it can be noted that the current scientific trends are developments - methodological, theoretical and experimental, related to improving the efficiency of some categories of luminaires with discharge lamps. One such category is the powerful industrial spotlight luminaires.

This work is aimed at solving the urgent scientific problem of finding ways to improve the design efficiency of industrial luminaires.

\section{METHOD OF CALCULATION OF THE OPTICAL SYSTEM} OF SPOTLIGHT CLASS APPLIANCES WITH REGULATED DEPTH AND CONCENTRATED LIGHT-DISTRIBUTION FOR DISCHARGE

\section{LAMPS OF CYLINDRICAL FORM}

When developing a new lighting fixture (LF) modification, the most important step is the lighting calculation of the reflector. The calculations of reflectors were previously carried out [1] in the framework of the elemental reflection (ER) method, the essence of which is to consider a light beam formed by LF, as a set of separate light beams - ER, the shape and dimensions of which are determined by the characteristics of the luminous body and the light source, and reflector characteristics (shape, material, etc.).

However, in [2] it was shown that the use of the algorithm for calculating the profile of the mirror reflector, proposed in [1] in terms of complexity, speed and quality of the end result is not rational. The fact is that this algorithm was based on the use of outdated hardware and software and the calculation itself was reduced to a consistent variation in the geometry of the reflector until it provided the necessary balance in the equation that relates the light power of the lamp with the light power of the light source and the reflector. The need for a computational program (which was absent, and in the well-known Trembach monograph [1] only the basic principle of its operation was given), considerable calculation time and obtaining decisions that are correct in terms of lighting, but meaningless from the point of view of technological orientation of the reflector construct. - all this led to a rethinking of the solution of the problem of calculating the geometry of the profile of the reflector with a rigidly regulated light distribution. Such a problem was formulated and solved in [2-3] in the first approximation and its essence is as follows. According to [2-3], the problem of reproducing the profile of a mirror reflector can be quickly and effectively solved by accurate graphoanalytic description of the required curve of the light force of the reflector by a set of zonal LPC. Thus obtained zone LPC , first, satisfy the necessary light distribution of the designed lamp and, secondly, is a source of information important for further calculations of the curvature of the reflector.

As is known, the zonal luminous intensity of the lamp $I_{\alpha}$ for the selected angle $\alpha$ is determined by the following expression [1]:

$$
I_{\alpha}=\rho \cdot L_{l . b} \cdot \kappa_{\alpha} \cdot A_{z} \cdot \cos \sigma_{\alpha},
$$

де $A_{z}$ - is the area of the selected zone, $L_{l . b--} L_{c . m}$ is the luminosity of the luminous body in the direction of $\varphi_{a}$ zone, $\kappa_{\alpha}-$ is the coefficient of filling the zone with the light part in the direction $\alpha, \sigma_{\alpha}$ - is the angle of projective reduction of the zone to the direction perpendicular to the direction $\alpha$.

Having zonal features (which fill the required LPC of the lamp as we need it), we actually know the value of $I_{\alpha}$.

The product of $\rho \cdot L_{l . b}$ is constant (of course, within the selected area). Namely, for lamps whose shape is approximately cylindrical [1]:

$$
\rho \cdot \Lambda_{\lambda . \beta}=\frac{\rho \cdot I_{\varphi a}}{A \cdot \cos \varphi_{a}},
$$

where A is the area of the luminous body (the geometry of which we know), $I_{\varphi_{a}}$ - the value of the light force of the lamp in the direction of the middle zone (also the value is known taking into account the known luminous flux of the lamp and a given curve of light power in conditional units (of the lamp type used).

According to $[2-3]$ :

$$
\begin{aligned}
& {\frac{I_{\alpha}}{\rho \cdot L_{l . b}}}_{l . b} \cdot \cos \sigma_{\alpha} \cdot \kappa_{\alpha}= \\
& =\frac{\pi^{2} \cdot \Delta \varphi \cdot \sin \varphi_{a} \cdot r_{a}^{2}}{90 \cdot \operatorname{cosi} i_{a}} \cdot \cos \sigma_{\alpha} \cdot \kappa_{\alpha},
\end{aligned}
$$

where $\Delta \varphi$ is actually the angular width of the zone, $r_{c p}$ is the average value of the radius vector that determines the geometric shape of the zone, $i_{a}=\varphi_{a}-\delta_{a}$ is the angle of the fall of the axial beam at the midpoint of the zone $\left(\delta_{a}=\frac{\left(\varphi_{0}+\alpha_{0}\right)+\left(\varphi_{1}+\alpha_{1}\right)}{4}\right.$, where $\varphi_{i}$ and $\alpha_{i}$ are the angles that form the fallen and reflected rays at the boundary points of the reflector zone with the axis [1-3].

By transferring to the left side of the equation all the parameters that can be considered known within the given task, and, taking the notation:

$$
\Lambda=\frac{I_{\alpha}}{\rho \cdot L_{l . b}} \cdot\left(\frac{90}{\pi^{2} \cdot \Delta \varphi \cdot \sin \varphi_{a}}\right),
$$

we get the following simple expression:

$$
\Lambda=r_{a}^{2} \cdot \kappa_{\alpha} \frac{\cos \sigma_{\alpha}}{\cos i_{a}}=r_{a}^{2} \cdot \kappa_{\alpha} \cdot \frac{\cos \left(\varphi_{a}-\delta_{\alpha}\right)}{\cos \left(\delta_{a}-\alpha\right)} .
$$




\begin{tabular}{|c|c|c|}
\hline Source type & DNaT & Unit, \\
\hline Power source, P $\boldsymbol{I}$ & 250 & $\mathrm{wt}$ \\
\hline The diameter of the flask & 58 & $\mathrm{~mm}$ \\
\hline The length of the flask & 240 & $\mathrm{~mm}$ \\
\hline Burner diameter & 8,9 & $\mathrm{~mm}$ \\
\hline Burner length & 75 & $\mathrm{~mm}$ \\
\hline Type of LPC & $\Gamma-2$ & \\
\hline The reflection coefficient of the reflector & 0,9 & \\
\hline Efficiency (lower boundary for TU) & 50 & $\%$ \\
\hline Intensification coefficient & $4 \sim 10$ & \\
\hline Source stream & 25000 & $\mathrm{~lm}$ \\
\hline Clearance, $\mathbf{R}^{*}$ & 35 & $\mathrm{~mm}$ \\
\hline
\end{tabular}

The latter expression is key in the proposed method. It allows [2-3] to make a triple connection - between the required value of $I_{\alpha}$, the function of the required course of rays (which is expressed in the parameter $\delta_{a}$ ) and the shape of the reflector $r_{a}$. Thanks to the above expression, these parameters can be selected in a consistent, single array, which is impossible using methods [1]. It can be seen that choosing the value of $r_{i}$ for each zone (such that the reflector would have a smooth and, moreover, the shape we need), and selecting the value of the parameter $\delta_{a}$ (according to the schemes given in [1]) we can determine the values of $\kappa_{\alpha}$ at which the compound equation holds. Thus, the shape of the reflector for each zone is calculated quickly and accurately, which provides the necessary LPC of the lamp.

Ideologically, this method is the closest to the existing method of "reversing the rays" [1], but it should be noted that while the method allows to reproduce the shape and characteristics of the luminous body of the source, this method solves the question of reproduction of the shape of the reflector.

\section{PERFORMANCE OF LIGHT TECHNICAL CALCULATION FOR INDUSTRIAL LIGHT OF ZHSP-250 TYPE}

The main task of this calculation is to determine the curvature of the reflector, which corresponds to the required LPC of this lamp. The basis for the lighting calculation is the original data. They consist of information of three types. The first type concerns the light source itself (lamp power and its geometry). The second concerns the light distribution of the future LF (Lighting Fixtures). The third characterizes the reflector material and the requirements for LF as a whole. The main purpose of the calculation is to calculate the set of radius vectors $\left\{r_{i}\right\}$ that define the profile of the mirror reflector.

"Blind opening" radius of the reflector: $R_{0}=R_{f}+R^{*}=\frac{1}{2} Д_{l}+R^{*}=64 m m$
Initial vector radius (upper bound of the reflector profile):

$$
r_{o}=\sqrt{R_{0}^{2}+h^{2}}=136 \mathrm{~mm}
$$

where $R_{0}$ - is the diameter of the neck of the reflector, $h=\frac{1}{2} \cdot 240 \mathrm{~mm}$ is half the length of the lamp.

Neck angle of the reflector (the boundary angle from which the angle profile of the LF profile begins to be taken into account): $\varphi_{0}=\arcsin \left(\frac{R_{0}}{r_{0}}\right)=28^{0}$.

Reflector coverage angle (see Figure 1):

$$
\varphi_{c . a}=90^{0}+\gamma_{a . p .}-\varphi_{0},
$$

where $\gamma_{a . p .}$ - is the axial protective angle, which is 20-35 degrees in typical lighting structures [1].

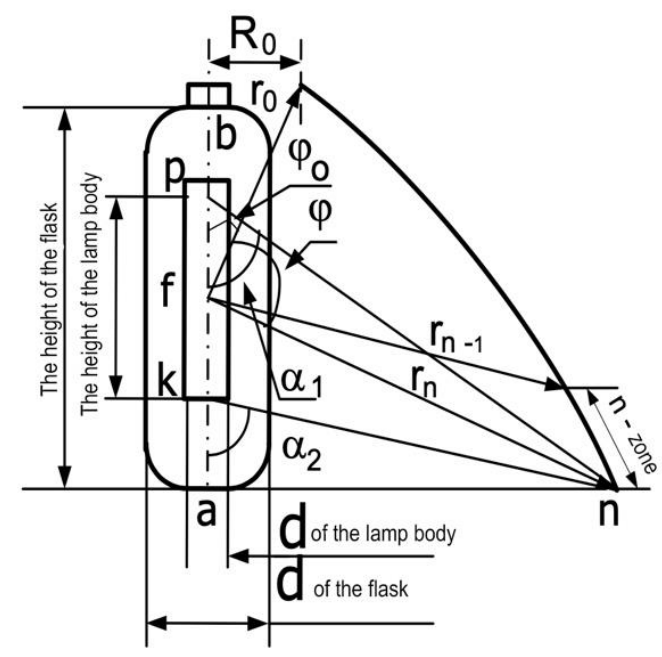

Fig. 1. Lamp reflector profile

So we accept $\gamma_{a . p .}=28^{0}$ and get $\varphi_{\text {c.a }}=90^{0}$. After converting the light source power from conventional units (for a 1000-lm DNaT conditional lamp) into real ones (under the required source flow), and after translating into actual units the required luminaire light power (taking into account the illumination of the lamp body by the edge of the reflector), which is a purely geometric problem, the solution of which we omit, we will get the necessary LPC (Light Power Curve) of the reflector.

The light curve of the light source in real units is shown in Fig. 2. 


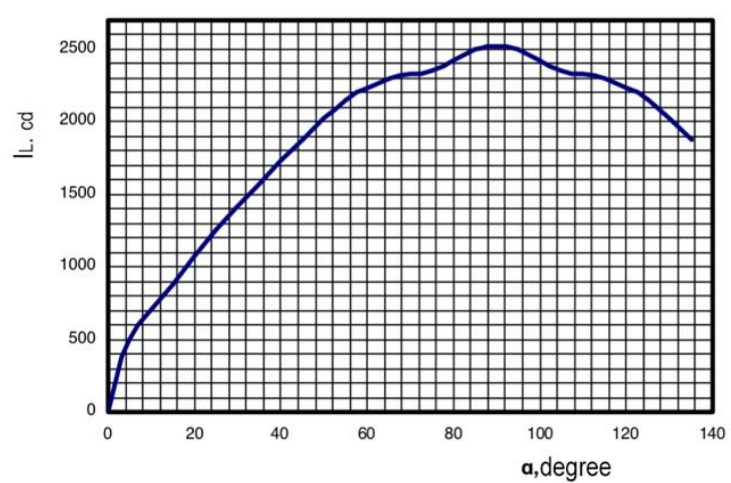

Fig. 2. LPC of the lamp DNaT-250

Starting from this point, the traditional lighting calculation [1] consisted of varying the size of the reflector zones and the magnitudes of the radius vectors that cut off the boundary points of each zone. Then, after selecting the next array of radius vectors $\{$ ri $\}$, the painstaking work of calculating the zonal reflector of the reflector has began. The work was considered successful when the sum of all zonal LPC was equal to the reflector LPC. This work has traditionally been long lasting and the accuracy of the end result in terms of reaching the required light distribution has been negligible.

Implementing our approach, defined in [2-3], we solve the problem in the opposite direction, namely, we obtain an array of zonal LPCs and consequently determine an array of radius vectors $\{$ ri $\}$ from them.

The result of the completed work is shown in Fig. 3.

We define a number of required characteristics for the constructed 6 zone LPC.

This is the average angle for each zone $\varphi_{\mathrm{a}}$ (calculated by the formula $\left.\varphi_{a}=\frac{\varphi_{i}+\varphi_{i+1}}{2}\right)$,

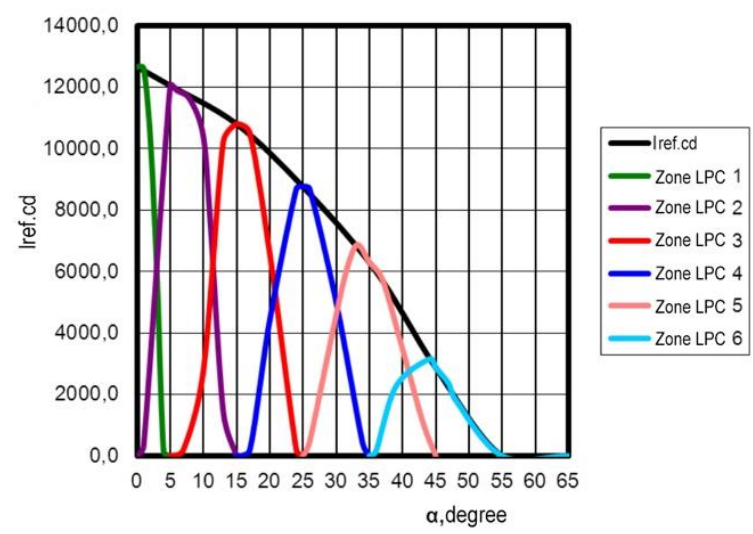

Fig. 3. Description of the required LPC of the reflector by the zonal LPCs.

the value of the light power of the lamp for this angle (determined by the dependence in Fig. 2), the average value of the radius vector (for each $\sigma_{\mathrm{a}}$ (calculated by the expression $\sigma_{\alpha_{\mathrm{a}}}=\frac{\left(\phi_{0}+{\Sigma_{0}}_{0}\right)+\left(\phi_{1}+\Sigma_{1}\right)}{4}$, we obtain the results of table 1 .

As can be seen from the results obtained, the reflector profile is sufficiently smooth. This was achieved by the fact that each subsequent radius vector differed from the previous one by a constant value of approximately $20 \mathrm{~mm}$.

Manufacturing of such a reflector profile does not cause any complications in the production. For this purpose, a pressure mandrel will be made, the geometry of which corresponds to the above calculation, after which the method of rotary extrusion may be used in case of using rolled aluminium. By the way, the reflection coefficient $\rho=0,9$ used in the calculations was taken into account such future technological operations as polishing the reflector and protecting its surface.

TABLE I. ALCULATION OF THE REFLECTOR GEOMETRY

\begin{tabular}{|c|c|c|c|c|c|c|c|c|c|}
\hline Zone & $\alpha^{0}$ & $\mathrm{I} \alpha, \mathrm{cd}$ & $\rho \cdot L_{l . b}$ & $\frac{90}{\pi^{2} \Delta \varphi \sin \varphi a}$ & $\wedge, m^{2}$ & $r_{1}, m m$ & $r_{a .}, M n$ & $\frac{\cos \left(\delta_{c p}-\alpha\right)}{\cos \left(\varphi_{c p .}-\delta_{c p .}\right)}$ & Ka \\
\hline \multirow[t]{6}{*}{ Zone 1} & 0 & 12669 & \multirow[t]{6}{*}{2,61} & \multirow[t]{6}{*}{1,05} & 570,90 & \multirow[t]{6}{*}{136} & \multirow[t]{6}{*}{145,92} & 1,16 & 0,2058 \\
\hline & 1 & 12620 & & & 5051,37 & & & 1,16 & 0,2048 \\
\hline & 2 & 10370 & & & 4150,77 & & & 1,16 & 0,1681 \\
\hline & 3 & 5970 & & & 2389,60 & & & 1,16 & 0,0967 \\
\hline & 4 & 160 & & & 64,04 & & & 1,16 & 0,0026 \\
\hline & 5 & 0 & & & 0,00 & & & 1,16 & 0,0000 \\
\hline \multirow[t]{6}{*}{ Zone 2} & 0 & 0 & \multirow[t]{6}{*}{4,25} & \multirow[t]{6}{*}{0,79} & 0,00 & \multirow[t]{6}{*}{156} & \multirow[t]{6}{*}{165,75} & 1,18 & 0,0000 \\
\hline & 5 & 12057 & & & 2234,94 & & & 1,20 & 0,0677 \\
\hline & 8 & 11600 & & & 2150,17 & & & 1,21 & 0,0646 \\
\hline & 11 & 7760 & & & 1438,39 & & & 1,22 & 0,0430 \\
\hline & 13 & 1440 & & & 266,92 & & & 1,22 & 0,0080 \\
\hline & 15 & 0 & & & 0,00 & & & 1,22 & 0,0000 \\
\hline \multirow[t]{6}{*}{ Zone 3} & 5 & 0 & \multirow[t]{6}{*}{7,20} & \multirow[t]{6}{*}{0,67} & 0,00 & \multirow[t]{6}{*}{176} & \multirow[t]{6}{*}{185,58} & 1,17 & 0,0000 \\
\hline & 7 & 200 & & & 18,70 & & & 1,19 & 0,0005 \\
\hline & 10 & 2760 & & & 258,07 & & & 1,21 & 0,0062 \\
\hline & 15 & 10808 & & & 1010,57 & & & 1,24 & 0,0237 \\
\hline & 20 & 6590 & & & 616,19 & & & 1,26 & 0,0142 \\
\hline & 25 & 0 & & & 0,00 & & & 1,26 & 0,0000 \\
\hline \multirow[t]{3}{*}{ Zone 4} & 15 & 0 & \multirow[t]{3}{*}{19,96} & \multirow[t]{3}{*}{0,62} & 0,00 & \multirow[t]{3}{*}{196} & \multirow[t]{3}{*}{205,42} & 1,25 & 0,0000 \\
\hline & 17 & 200 & & & 6,17 & & & 1,27 & 0,0001 \\
\hline & 20 & 4420 & & & 136,46 & & & 1,29 & 0,0025 \\
\hline
\end{tabular}




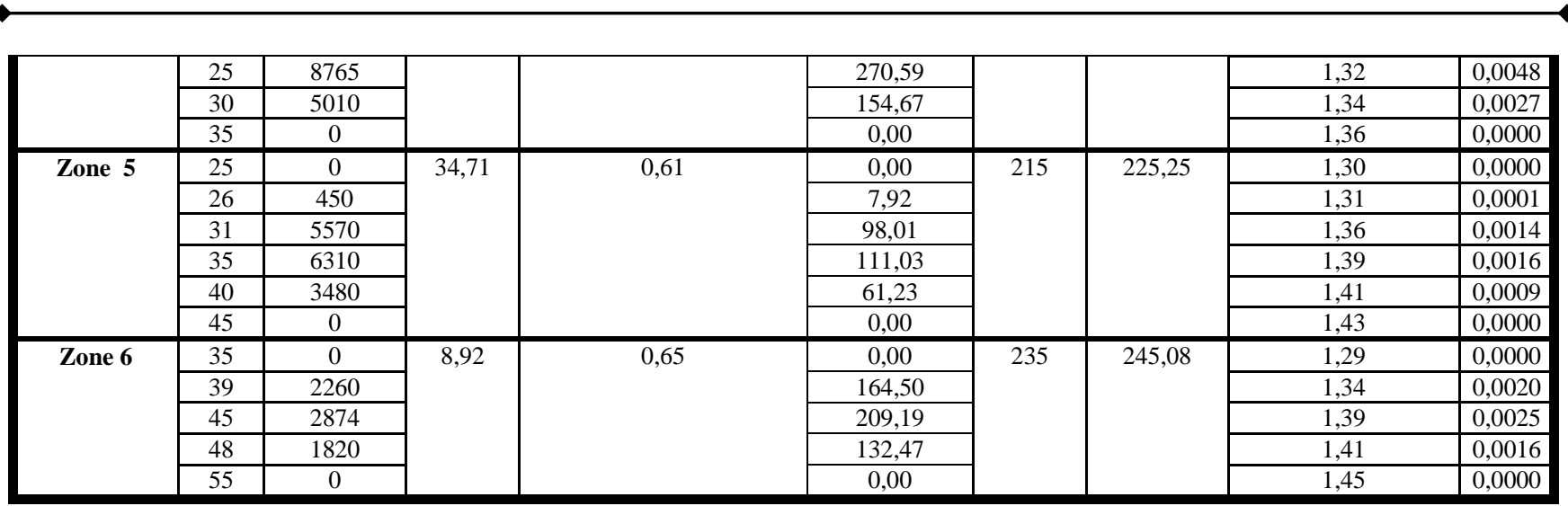

The calculation of the efficiency and the gain coefficient of the designed housing ZhKU-250 gave the result:

$$
\begin{gathered}
\eta=\frac{\Phi_{l . d .}}{\Phi_{l}}=\frac{14298}{25000}=57,19 \% . \\
K_{u_{l}}=\frac{I_{l . d .}(\max )}{I_{l}(\max )}=\frac{12668,8 c d}{2520 c d}=5,03 .
\end{gathered}
$$

The results obtained fully satisfy the requirements for the development of industrial luminaires.

\section{WORKING CONCLUSIONS}

Based on a comparative analysis of modern luminaires with different light sources, the urgent task of creating new modifications of industrial luminaires with discharge lamps was determined. The calculation method of calculation of the profile geometry of the mirror reflectors of industrial luminaires is presented, which provides the necessary luminous distribution of the luminaire at a fixed power of the light source. Testing of the technique on the light sources
DNAT-250 was performed. It is shown that the use of the calculation algorithms proposed by the authors made it possible to design a ZhSP-250 lamp with regulated G-2 light distribution for specific objects of operation. It is possible to note the efficiency of the method both in terms of the accuracy of the calculations and the simple geometry of the reflector, obtained in the calculation method, which will allow to use simplified technological schemes for the serial production of such lamps.

\section{REFERENCES}

[1] Trembach V.V. Svetovy`e prybory`. M: Vy`sshaia shkola, 1990. $462 \mathrm{~s}$.

[2] Balandaeva L.G., Petchenko G.A., Tokman A.I. E`ffektivnaya metodika rascheta formy zerkal'nogo otrazhatelya svetil'nika s trebuemoj KSS // Kommunal'noe xozyajstvo gorodov. - № 53. 2003.- s. 207-210.

[3] Petchenko G.A., Gurakova L.D., Balandaeva L.G., Xixlya T.A., Stepura V.I. Reshenie obratnoj zadachi primenitel'no k naxozhdeniyu optimal'nogo profilya zerkal'nogo kruglosimmetrichnogo otrazhatelya $v$ ramkax metoda elementarnix otobrazhenij // Svetotexnika i e'lektroenergetika. - № 1. - 2007.- s. $40-44$.

\section{Методика розрахунку профіля дзеркального відбивача для розрядних ламп циліндричної форми і їі апробація на прикладі проектування промислового світильника типу ЖСП-250}

\author{
Є.Е. Лобанов \\ ХНУМГ ім. О.М. Бекетова, \\ Україна
}

\author{
Г.О. Петченко \\ ХНУМГ ім. О.М. Бекетова, \\ Україна
}

Аннотація - актуальними на сьогодні науковими напрямками с розробки - методологічні, теоретичні i експериментальні, пов'язані 3 підвищенням ефективності деяких категорій світильників 3 розрядними лампами. Однісю 3 таких категорій є потужні промислові світильники прожекторного класу. Дана робота спрямована на вирішення актуального наукового завдання пошуків шляхів підвищення ефективності проектування промислових світильників 3 глибоким і концентрованим світлорозподілом. На сьогоднішній час практично немас робіт, які б відноситись до задачі розрахунку геометрії профілів дзеркальних круглосиметричних відбивачів, які за наявності джерела світла фіксованого типу і потужності забезпечували необхідний світлорозподіл світильників. Метод елементарних відображень, який описано у класичних роботах, не дозволяє коректно визначити геометрію відбивача, яка забезпечус необхідний баланс у рівнянні, яке пов'язус силу світла світильника $з$ силою світла джерела і відбивача. Значний час розрахунку класичним методом і одержання неточних рішень спонукає до переосмислення вирішення задачі розрахунку геометрії профіля відбивача світильника 3 жорстко регламентованим світлорозподілом. Така задача була у першому наближенні сформульована нами у попередніх роботах. Метою даної роботи с апробація 
Ye. Lobanov, G. Petchenko Issue 57, Vol. 01.

методики рішення зворотної задачі визначення геометрії круглосиметричного дзеркального відбивача на прикладі промислового світильника типу ЖкУ-250 зі світлорозподілом типу Г-2. Як вихідний масив даних для виконання розрахунку використовувались світлотехнічні і технічні характеристики джерела світла - лампи ДНаТ-250, необхідний світлорозподіл світлового приладу, коефіціснт дзеркального відбиття відбивача, а також вимоги до КкД проектованого світильника i його коефіцієнта підсилення. В результаті виконаної роботи можна відзначити ефективність методики як у плані точності розрахунків, так і простій геометрії відбивача, одержаній у розрахунковий спосіб, що дозволить використовувати спрощені технологічні схеми при серійному виготовленні таких світильників.

Ключові слова - промислові світильники, розрядні лампи типу ДНаТ, необхідна КСС відбивача, зональні КСС відбивача, масив радіус-векторів, коефіцієнт підсилення і ККД світильника, метод елементарних від ображень, профіль відбивача, метод ротаційного видавлювавння. 